\title{
SESQUITERPENES OF AMAZONIAN Piper SPECIES*
}

\author{
Alberdan S. SANTOS' ${ }^{1}$, Eloisa H.A. ANDRADE ${ }^{1}$, Maria das Graças B. \\ ZOGHBI', Arnaldo I.R. LUZ ${ }^{2}$, José G.S. MAIA ${ }^{3}$
}

\begin{abstract}
The essential oils from leaves and thin branches of Piper amapense, Piper duckei and Piper bartlingianum were analysed by GC/MS and all volatile compounds were identified as sesquiterpenes. The main constitutents identified in the oil of $P$. amapense were transcaryophyllene $(25.0 \%)$, caryophyllene oxide $(17.0 \%)$ and $\beta$-selinene $(15.0 \%)$. The oil of $P$. duckei was dominated by trans-caryophyllene $(23.5 \%)$, caryophyllene oxide $(18.4 \%), \beta$-eudesmol $(9.4 \%)$ and $\alpha$-eudesmol $(9.1 \%)$. The major components found in the oil of $P$. bartlingianum were $\alpha$ cadinol $(11.2 \%), \beta$-elemene $(10.5 \%), \alpha$-muurolol $(9.4 \%),(E)$-nerolidol $(9.0 \%)$.
\end{abstract}

Key words: Piper amapense, Piper duckei, Piper bartlingianum, Piperaceae, Essential oils, Sesquiterpenes.

\section{Sesquiterpenos de Espécies de Piper da Amazônia.}

RESUMO - Os óleos essenciais obtidos das folhas e galhos finos de Piper amapense, Piper duckei e Piper bartlingianum foram analisados por GC/MS. Os óleos dessas espécies são constituídos na sua totalidade por sesquiterpenos. Os principais constituintes identificados no óleo de $P$. amapense foram trans-cariofileno (25,0\%), óxido de cariofileno $(17,0 \%)$ e $\beta$-selineno $(15,0 \%)$. O óleo de $P$. duckei foi dominado por trans-cariofileno $(23,5 \%)$, óxido de cariofileno $(18,4 \%), \beta$-eudesmol $(9,4 \%)$ e $\alpha$-eudesmol $(9,1 \%)$. Os mais importantes componentes encontrados em $P$. bartlingianum foram $\alpha$-cadinol $(11,2 \%), \beta$-elemene $(10,5 \%), \alpha$-muurolol $(9,4 \%),(E)$-nerolidol $(9,0 \%)$.

Palavras-chave: Piper amapense, Piper duckei, Piper bartlingianum, Piperaceae, óleos essenciais, sesquiterpenos.

\section{INTRODUCTION}

The family Piperaceae comprises 12 genera and about 1400 species of mainly pantropical distribution (Barroso, 1978). Piper species are found in all the world's tropical rainforests and are the dominant understory species in many Neotropical forests. The genus contains more than 700 species, of which about 170 grow wild in Brazil (Yuncker, 1972). The medicinal uses of Piper species include treatments for venereal diseases, intestinal disorders (Addae-Mensah et al., 1977), genito-urinary-maladies, epilepsy and to prevent conception (Atal et al., 1975). Traditionally they are also used against pests (Bernard et al., 1995). Piper bartlingianum is a shrub of wide distribution in northern Brazil, were it is used as fish-poison (Acevedo-Rodríguez, 1990). The amide dihydropiplartine was isolated from its benzene extract (Kijoa et al., 1982). Investigations on the constituents of the volatile oil of these species have not been reported previously. This paper reports the chemical composition of the essential oils of Piper amapense, Piper duckei and Piper bartlingianum.

1 Museu Paraense Emílio Goeldi, Departamento de Botânica, CP 399, 66040-170, Belém, PA, Brasil

2 Instituto Nacional de Pesquisas da Amazônia, Coordenação de Pesquisas em Produtos Naturais, CP 478, 69011-970, Manaus, AM, Brasil

3 Universidade Federal do Pará, Departamento de Química, CP 8600, 66075-900, Belém, PA, Brasil

* Part 2 in the Series "The Volatile Constituents of Brazilian Piperaceae" 


\section{MATERIAL AND METHODS}

The leaves and thin branches of the collected Piper species were airdried for seven days and water-distilled for two hours. The oil obtained was dried over anhydrous sodium sulphate and the yield was calculated based on dry weight of the plant material. Voucher of $P$. bartlingianum (\#151560) is kept at the Herbarium of the Museu Paraense Emilio Goeldi. The vouchers of Piper amapense and $P$. duckei (\#188196 and \#188187, respectively) are kept at the Herbarium of the Instituto Nacional de Pesquisas da Amazônia. Plant identification was carried out by the botanist Elsie Franklin Guimarães, Jardim Botânico, Rio de Janeiro, Brazil. The collection data and oil yield are presented in Table 1 .

The essential oil was analysed with a GC/MS system (gas chromatograph model VARIAN 3400 , mass spectrometer, FINNINGAN model INCOS-XL) with the following conditions: column: DB-5 fused silica (30 $\mathrm{m} \times 0.25 \mathrm{~mm}$ i.d.; $0.25 \mu \mathrm{m}$ film thickness); carrier gas: helium, adjusted to a linear velocity of $32 \mathrm{~cm} / \mathrm{sec}(1 \mathrm{~mL} /$ $\mathrm{min})$ measured at $100^{\circ} \mathrm{C}$; injector temperature: $220^{\circ} \mathrm{C}$; temperature programmed: $60^{\circ} \mathrm{C}-240^{\circ} \mathrm{C}\left(3^{\circ} \mathrm{C} / \mathrm{min}\right)$; injection type: splitless $(1 \mu \mathrm{l}$ of a 1:1000 n-hexane solution); mass spectra: 70 $\mathrm{eV}$ (in EI mode). Individual volatile components were identified by com- parison of both mass spectra and their GC retention data with those of authentic standards previously stored in the data system. Other identifications were made by comparison of mass spectra with those in the data system libraries and the literature (Adams, 1995). The retention indices were calculated for all volatile constituents using a homologous series of $n$-alkanes. The compounds identified in the oils of Piper amapense, $P$. duckei and $P$. bartlingianum are listed in Table 2 .

\section{RESULTS AND DISCUSSION}

The essential oils of analysed Piper species were characterized by the presence of sesquiterpenes. The major compounds identified in the oil of $P$. amapense were transcaryophyllene $(25.0 \%), \beta$-selinene $(15.0 \%)$ and caryophyllene oxide $(17.0 \%)$. The oil of $P$. duckei was dominated by trans-caryophyllene $(23.5 \%)$, caryophyllene oxide (18.4\%), $\beta$-eudesmol $(9.4 \%)$ and $\alpha$ eudesmol $(9.1 \%)$. The main volatile components found in $P$. bartlingianum were $\alpha$-cadinol $(11.2 \%), \beta$-elemene $(10.5 \%), \alpha$-muurolol $(9.4 \%)$, (E)nerolidol. The sesquiterpene hydrocarbons $\alpha$-copaene, trans-caryophyllene and spathulenol were present in the oils of all analysed species. In general, the essential oils of Piper species from Amazonia are rich on mono- and ses-

Table 1. Identification, collection data and essential oil yield of the three Piper species studied.

\begin{tabular}{|c|c|c|}
\hline Species & Local of collection & Oil (\%) \\
\hline Piper amapense Yunck. & Km 26, Manaus/Itacoatiara highway, AM & 0.6 \\
\hline P. duckei C. DC. & Km 26, Manaus/Itacoatiara highway, AM & 0,4 \\
\hline P. bartlingianum (Miq.) C.DC. & Km 1, Manaus/Porto Velho highway, AM & 0.3 \\
\hline
\end{tabular}


Table 2. Volatile constituents identified in the essential oils of Piper species.

\begin{tabular}{|c|c|c|c|c|}
\hline Constituents & $\begin{array}{c}\text { Retention } \\
\text { index }\end{array}$ & $\begin{array}{c}\text { P. amapense } \\
(\%)\end{array}$ & $\begin{array}{l}\text { P. duckei } \\
(\%)\end{array}$ & $\begin{array}{c}\text { P. bartlingianum } \\
(\%)\end{array}$ \\
\hline$\alpha$-Copaene & 1376 & 2,2 & 1.6 & 0.9 \\
\hline$\beta$-Elemene & 1392 & & & 10.5 \\
\hline trans-Caryophyllene & 1420 & 25,0 & 23.5 & 5.9 \\
\hline$\alpha$-Humulene & 1451 & 2,2 & 3.3 & \\
\hline allo-Aromadendrene & 1461 & 4,1 & & \\
\hline$\gamma$-Muurolene & 1477 & & & 3.0 \\
\hline Germacrene D & 1481 & 2,6 & & \\
\hline$\beta$-Selinene & 1488 & 15,0 & & \\
\hline$\alpha$-Selinene & 1496 & & & 4.0 \\
\hline trans- $\beta$-Guaiene & 1502 & & & 5.2 \\
\hline 1S,cis-Calamenene & 1524 & & & 3.4 \\
\hline Elemol & 1550 & 4,8 & & \\
\hline (E)-Nerolidol & 1566 & & 2.4 & 9.0 \\
\hline Spathulenol & 1579 & 5,1 & 5.2 & 7.8 \\
\hline Caryophyllene oxide & 1584 & 17,0 & 18.4 & \\
\hline Globulol & 1586 & & & 7.7 \\
\hline Guaiol & 1599 & 5,3 & & \\
\hline Humulene epoxide $\|$ & 1610 & 4.2 & & \\
\hline 1-epi-Cubenol & 1629 & & 2.8 & 8.0 \\
\hline$\gamma$-Eudesmol & 1631 & & 4.3 & \\
\hline epi- $\alpha$-Muurolol & 1643 & & 3.0 & 7.3 \\
\hline a-Muurolol & 1648 & & 5.7 & 9,4 \\
\hline$\alpha$-Cadinol & 1658 & & & 11.2 \\
\hline$\beta$-Eudesmol & 1651 & & 9.4 & \\
\hline$\alpha$-Eudesmol & 1653 & & 9.1 & \\
\hline Bulnesol & 1669 & 5.6 & & \\
\hline
\end{tabular}

quiterpenes, like the present examples, or arylpropanoids, as cited by Maia $e t$ al. (1987) and Gottlieb et al. (1981).

\section{ACKNOWLEDGMENTS}

This work was supported by the Academia Brasileira de Ciências. The authors are grateful to Dr Ozório José de Menezes Fonseca (INPA) and Dr Claude Gascon (INPA/Smithsonian Institution) for their assistance in plant collection and Dr Elsie Franklin Guimarães (Jardim Botânico, Rio de Janeiro) for plant identification.

\section{Literature cited}

Acevedo-Rodriguez, P. 1990. The occurrence of piscicides and stupefactants in the plant kingdom. Advances in Economic
Botany, 8:1-23.

Adams, R.P. 1995. Identification of Essential Oil Components by Gas Chromatography/Mass Spectroscopy. Allured Publishing Corporation, Illinois, USA, 469p.

Addae-Mensah, I.; Torto, F. G.; Dimonyeka, C. I.; Baxter, 1.; Sanders, J. K. M. 1977. Novel amide alkaloids from the roots of Piper guineense. Phytochemistry, 16:757-759.

Atal, C. K;; Dhar, K. L.; Singh, J, 1975. The chemistry of Indian Piper species. Lloydia, 38(3):256-264.

Barroso, G. M. 1978. Sistemática de angiospermas do Brasil. Vol 1. São Paulo, Epu; Usp, p. 45.

Bernard, C. B.; Krishnamurty, H. G.; Chauret, D.; Durst, T.; Philogène, B. J. R.; SánchezVindas, P.; Hasbum, C.; Poveda, L.; San Román, L.; Arnason, J. T. 1995. Insecticidal defenses of Piperaceae from the 
neotropics. J. Chem. Ecol., 21:801.

Gottlieb, O.R.; Koketsu, M.; Magalhães, M.T.; Maia, J.G.S.; Mendes, P.H.; da Rocha, A.I.; da Silva, M.L.; Wilberg, V.C. 1981. Óleos essenciais da Amazônia VII, Acta Amazonica, 11:143.

Kijoa, A.; Giesebrecht, A. M.; Gottlieb, O. R. 1982. Dihydropiplartine from Piper bartlingianum. Planta Medica, 44(3): 188.

Maia, J.G.S.; da Silva, M.L.; Luz, A.I.R.; Zoghbi, M.G.B.; Ramos, L.S. 1987. Espécies de Piper da Amazônia ricas em safrol. Quimica Nova, 10:200.

Yuncker, T. G. 1972. The Piperaceae of Brazil. Hoehnea, 2:1-366. 